\title{
Hukuksal Ampirizmin Hukuk Disiplini Yöntemi Olarak Ortaya Çıkışı ve Erken Gelişim Dönemi: Petrazycki ve Ehrlich'in Görüşleri
}

\author{
Şefik Taylan Akman (i)
}

Öz

Liberal hukuk düzenleri Aydınlanma döneminin ve burjuva devrimlerinin ardından ortaya çıkmıştır. 19. yüzyıl kanunlaştırmaları ile biçimlenen liberal hukuk düzenleri içinde hukukçular, hukuka özgülenmiş bir metodoloji geliştirmeye yönelmişlerdir. Farklı hukuki pozitivizmlerin doğup geliştiği bu dönemde, hukukun kendi başına ilerleyen ve ayrı bir bilimsel alana dönüştürülmesi amaçlanmıştır. Bu uğraşı 19. yüzyıl hukuk metodolojisini hukuk dışı alanlara kapalı, sadece normatif düzenlemelerle ilgilenen ve hukukçulara has bir çalışma sahası olarak görmüştür. Hukuk düzeni her ne kadar toplumsal alanı ve ilişkileri düzenlemeye yönelmiş bir niteliği haiz olsa da geleneksel hukukçuluk kendisini normatif çerçeveyle sınırlandırarak toplumsal olguları görmezden gelmeyi tercih etmiştir. Bu durumun zamanla hukuk düzeni ile toplumsal gerçeklik arasında çatışmalara ve uyumsuzluklara yol açtığı fark edilmiştir. Dolayısıyla hukuksal analizin salt hukuki materyaller ile değil sosyal bilimlerin bulguları ile bir arada değerlendirilmesine yönelik görüşler öne sürülmüştür. Böylece başta ampirik metot olmak üzere hukuk ile sosyal bilimler arasında disiplinler arası araştırmanın imkânları tartışılmaya başlanmıştır.

Çalışmada 19. yüzyıldan 20. yüzyıla geçiş sürecinde hukuk metodolojisindeki bu değişim incelenecektir. 19. yüzyıl hukuki pozitivizmlerinin nitelik ve işlevleri genel olarak ele alındıktan sonra hukukta disiplinler arası metodolojilerin imkânı sorgulanacaktır. Bu kapsamda ilk olarak Leon Petrazycki'nin psikolojizm ve hukuk anlayışı, ardından Eugen Ehrlich'in yaşayan hukuk kavramı ampirik yöntemin hukukta kullanımı açısından değerlendirilecektir. Bu iki hukukçunun görüşleri üzerinden hukuksal ampirizmin hukuk disiplini içinde bir yöntem olarak ortaya çıkışı ve erken gelişim dönemi analiz edilecektir.

\section{Anahtar Kelimeler}

Hukuk ve sosyal bilimler ilişkisi, Hukukta disiplinler arası çalışmalar, Hukuksal ampirizm, Leon Petrazycki, Eugen Ehrlich

Appearance and Early Development Period of Legal Empiricism as the Method of the Discipline of Law: Views of Petrazycki and Ehrlich

\begin{abstract}
Liberal legal systems ensued after the Enlightenment period and bourgeois revolutions. Jurists have been inclined to improve a methodology specific to the law within the liberal legal systems formed by 19th-century codifications. In this period in which different legal positivisms were born and developed, the aim was to transform the law into a separate, self-propelling scientific field. This effort considered 19th-century legal methodology as a field of study for jurists, closed to non-legal areas, and concerned only with normative arrangements. Although the legal system has the characteristics to regulate the social sphere and relations, traditional lawyering has limited itself to the normative framework and ignored social facts. This situation causes conflicts and discrepancies between the legal system and social reality. Accordingly, arguments have been submitted to evaluate the legal analysis together with the outcomes of social sciences, not merely legal materials. Thereby, the possibilities of interdisciplinary research between law and social sciences, especially using the empirical method, have started to be discussed.

This article discusses the alteration in legal methodology throughout the transition period during the 19th-century and early 20th-century. First, the characteristics and functions of the 19th-century legal positivisms in general are scrutinized, and the possibility of interdisciplinary methodologies of law is questioned. Within this scope, first, Leon Petrazycki's
\end{abstract}

* Sorumlu Yazar: Şefik Taylan Akman (Dr. Öğr. Üyesi), Hacettepe Üniversitesi, Hukuk Fakültesi, Hukuk Felsefesi ve Sosyolojisi Anabilim Dalı, Ankara, Türkiye. E-posta: taylanakman@hacettepe.edu.tr ORCID: 0000-0002-7809-8664

Atıf: Akman ST, "Hukuksal Ampirizmin Hukuk Disiplini Yöntemi Olarak Ortaya Çıkışı ve Erken Gelişim Dönemi: Petrazycki ve Ehrlich'in Görüşleri” (2021) 79(1) İstanbul Hukuk Mecmuası 251. https://doi.org/10.26650/mecmua.2021.79.1.0007 
understanding of psychologism and law, subsequently Eugen Ehrlich's living law concept, are evaluated in terms of the use of the empirical method in law. Appearance and the early development period of legal empiricism as a method in the discipline of law are analyzed based on the opinions of these two jurists..

\section{Keywords}

Relationship of law and social sciences, Interdisciplinary studies at law, Legal empiricism, Leon Petrazycki, Eugen Ehrlich 


\section{Extended Summary}

The disciplinary relationship of jurists with the social sciences has always been limited. Many jurists have preferred to remain distant from the findings of the social sciences for reasons stemming from the normative structure of law. Accordingly, the field of law is considered a self-enclosed, autonomous area to the social sciences. This assumption has emerged as a founding principle of liberal legal systems. Liberal legal systems historically ensued after the Enlightenment period and bourgeois revolutions. Jurists have been inclined to improve a methodology specific to the law within the liberal legal systems formed by the 19th-century codifications. In this period, legal positivisms were born and developed, and the aim was to transform law into an independent self-enclosed scientific field. Thus, legal topics and studies of liberal legal systems have been accepted as the work of professionals in the unattainable area of jurists. This effort identifies the 19th-century legal methodology as a closed sphere to non-legal disciplines. According to this phenomenon, jurists should only be concerned with normative order as a field of study. Therefore, the jurists' law was formed. Although this law is based on social reality when it regulates social life, it has been detached from that reality because of these methodological concerns regarding the doctrine and the practice. Analyzing formal aspects of normative regulations and sustaining the commitment of objectivity identified with the idea of justice have become jurists' main purposes.

After scrutinizing the characteristics and the functions of the 19th-century legal positivisms in general, this article discusses the alteration in legal methodology during the transition period during the 19th-century and early 20th-century. Within this scope, first, Leon Petrazycki's understanding of psychologism and law and then Eugen Ehrlich's living law concept are evaluated in terms of the use of the empirical method in law. The rise and the early development period of legal empiricism as a method in the discipline of law are analyzed through the endeavors of these two jurists.

Petrazycki wanted to apply Comte's sociological methodology and the social sciences' to law. Through his methodological approach, which he called the science of legal policy, he worked on establishing his theory of law based on empiricalpsychological causality. He defined law as a special discipline that aims to ensure the progress and improvement of the existing legal system while promoting the construction of a democratic society. Petrazycki applied scientific objectivity to his legal approach. He separated his conception of law from all traditional understandings. According to him, none of the legal theories of his time, except his approach, had a scientific character and successfully explained the legal reality.

At this point, law established a relationship between the social sciences and psychology. Petrazycki replaced traditional legal methodologies with the empirical 
method. In this respect, on the one hand, the field of law was excluded from the normative and the prior assumptions, the formalist logic of positivism, and the dogmatic legal science; on the other hand, it was associated with the social sciences through the extension of experimental and observational processes. Although law was concretized in social reality in this manner, Petrazycki's theory of law was a sociological approach to law that emphasized implementing psychological verities to law. His research on legal analysis focused on individuals' experience of legal phenomena. His approach influenced jurists, and he discussed the relationship between law and society. His approach influenced the development of methodologies based on observation and empirical research in law.

Ehrlich, by contrast, applied his legal approach and established a specific relationship between the positive law and the living law. From this perspective, he concentrated on social and legal norms. Similar to Petrazycki, Ehrlich did not adopt legal positivist arguments and implied that law could be purely studied by using legal apparatus. He accepted legal analysis as an interdisciplinary field and brought empirical methods to the forefront. He tended to establish a new connection between legal studies and the social sciences, particularly between law and sociology, by adopting a scientific perspective. From Ehrlich's standpoint, traditional lawyering degraded legal studies to a relativistic technique that followed variable practical aims for the needs of centralized government and its courts, and this aspect also masked the current social phenomena by means of law. Jurists who adopted traditional methods could understand legal reality only at the superficial level through artificial systemizations and conceptualizations. The reason for the superficial understanding of jurists was that they perceived the social phenomena only within the framework of a legal worldview. They commentated on social phenomena from a purely normative perspective and adjudicated on a matter with this view. According to Ehrlich, jurists should have observed the social phenomena and analyzed them scientifically with reference to the social sciences, especially to sociology. They should have examined the legal topics by establishing a cause-effect relationship between these phenomena.

Consequently, neither Petrazycki nor Ehrlich considered law alone as a normative structure. They associated law with disciplines of the social sciences from a much broader perspective than the hypothesis of legal positivism and the other normative legal theories. Their legal approaches were based on interdisciplinary methodologies. By associating law with the social sciences, Petrazycki and Ehrlich have made observations and empirical inquiries a part of legal studies. For all the aforementioned reasons, they will affect the praxis of many jurists and researchers studying the relationship between law and the social sciences in the upcoming periods of the 20th century. 


\section{Hukuksal Ampirizmin Hukuk Disiplini Yöntemi Olarak Ortaya Çıkışı ve Erken Gelişim Dönemi: Petrazycki ve Ehrlich'in Görüşleri}

\section{Giriş: Geleneksel Hukukçuluk ve Hukuksal Alanın Dışa Kapalılığı}

Hukukçuların sosyal bilimler ile disiplin yönünden ilişkisinin her zaman sınırlı bir çerçevede kaldığı, hatta sosyal bilimlerin bulgularıyla, genel anlamda hukukun kendi normatif yapısından kaynaklı nedenlerden dolayı uzlaşmazlık içinde bulundukları söylenebilir. Liberal hukuk düzenlerinde bu uzlaşmazlığın ortaya çıkışında özellikle 20. yüzyılın başına kadar hukuksal fenomenleri hukukçular sınıfının dokunulmaz alanında ve meslek mensuplarının kıymeti kendinden menkul bir uğraşısı olarak gören anlayış baskın rol oynamıştır ${ }^{1}$. Böylece hukukçuların hukuku oluşmuş ve bu hukuk, toplumsal yaşamı düzenlemeye yöneldiği ölçekte bizatihi olgusal düzeyde bir gerçekliği imlediği halde doktrin ve uygulamanın metodolojik kaygıları neticesinde o gerçeklikten, normatif düzenlemelerin formel görünümlerine bağlllık ve adalet idesinin objektiviteyle özdeşleşen tarafsızlık taahhüdünün sürdürülebilmesi gibi kaygılarla uzaklaşmıştır.

Hukuk teorisiyle uygulamasının toplumsal pratiğe yabancılaşması olarak nitelendirilebilecek bu sonucun ortaya çıkış nedeni, hukuksal süreçlerde yer alan aktörlerin toplumsal gerçeklikleri yeteri kadar önemsemeyip hukuksal sorunların çözümünde salt pozitivist kabullerden hareket eden bir metodolojiyi benimsemeleri ve kendilerini sosyal bilimlerin bulgularından -hukukun esasen ayrı ve özel bir konumu, işlevi ve yöntemi olduğu gibi gerekçelerle- izole etmelerinden kaynaklanmaktadır. Böylece kendi içinde kapalı, formalist, bâtıni yorum kalıpları ve anlamlandırma süreçleriyle biçimlenmiş bir disiplin olarak hukuk, toplumsal gerçekliklerden uzak ve soyut bir yapıya dönüşmüştür. Hukukun yeniden toplumsal alanın gerçekliğiyle işleyişine ilgi duyması ve aynı zamanda toplum ile ilgili olanı araştırmaya yönelen sosyal bilimler disiplinlerini değerlendirmeye başlaması, onlarla ilişkiye geçmesi ancak hukukun sosyolojik cihette bir olgu olduğunun kabul edilmesiyle gündeme gelebilmiştir. Bu aşamada bilhassa sosyolojinin hukuka ve toplum içinde yaşanan hukuksal süreçlere yönelik artan ilgisi, hukukun kendi yapısal niteliği ve toplumsal fonksiyonunun sorgulanmasına yol açmıştır. Hukukun salt formel bir kurallar ve düzenlemeler yığını olmaktan öte toplumsal ve siyasal düzen işlevi gördüğü anlaşılmıştır. Örneğin hukuk sosyolojisi ancak söz konusu aşamadan sonra kendini hukukun içinde özgün bir araştırma sahası olarak kabul ettirebilmiştir. Keza hukukun formalist ve normatif karakterinin ötesinde toplumsal olan yönüyle de değerlendirilmesi ve yeniden anlamlandırılması gerektiği düşüncesi, hukukun geçmişi düşünüldügünde geç bir tarihte, hukuk sosyolojisinin gelişmesiyle koşut bir süreçte olgunlaşabilmiştir. Hukukun sosyolojik perspektiften incelenmesini müteakip gerek

Petrazycki'e göre de 19. yüzyılın sonuna kadar hukuk biliminin görevi sadece pozitif hukukun incelenmesi ve işleyişinin ortaya konulması olarak anlaşılmıştır. Leon Petrazycki, Law and Morality (Hugh W. Babb tr, Harvard 1955), 222. 
hukukçuların gerek sosyal bilimcilerin yoğunlaşan ilgileri sonucu, hukuk ile sosyal bilimlerin bulguları arasında bağlantılar oluşturulabilmiş ve hukuka ilişkin, başta sosyoloji olmak üzere sosyal bilimlerde yürütülen araştırmaları da değerlendirmeye yönelen yeni bir metodolojik arayış ilk nüvelerini vermeye başlamıştır.

Hukukun sosyal bilimlerle tanışması, hukukta o zamana kadar tartışılmayan, görülmeyen bir takım sorunlu alanların varlığını gün yüzüne çıkarmıştır. Başta metodolojik araştırmaya ilişkin farklılıklar olmak üzere hukuk ile sosyal bilimlerin yapısal karakterlerindeki ayrılıklar sosyal bilimlerin ortaya koyduğu tespitlerin hukuksal düzeyde karşılık bulabilmesini ve hukukun formalist sistematiğiyle kolayca bütünleşebilmesini engellemiştir. Bu bağlamda gerek hukuk düzeninin işleyişi ve tümelliğinin gerek hukuksal aktörlerin muhafazakâr ve statükocu tutumlarının sosyal bilimler metodolojisinin geniş anlamda hukuksal kurum ve süreçlere nüfuz etmesini frenleyici bir işlev gördügünü söylemek yanlış olmayacaktır. Muhafazakârlık, öncelikle yeni metodolojik arayışları aksattığı gibi usul yönünden zenginleşmeyi de kısıtlamış; daha da önemlisi sosyal bilimlerin toplumsal gerçeklik, ekonomik ve politik süreçlerin anlamlandırılmasına yönelmiş bulgularını da hukukun formalist karakterine atıf ile hukuksal istikrar ve öngörülebilirliğin bozulmaması gibi gerekçelerle çoğunlukla görmezden gelmeyi yeğlemiştir. Ancak bu eğilimin olumsuz yansımalarının öncelikle hukuksal düzeyde ortaya çıktığı ve hukukun toplumsal bir düzen olarak işleyişinin anlaşılabilirliğine ket vurduğu belirtilmelidir.

Sosyal bilimciler, toplumsal süreç ve olguların anlaşılabilmesi hedefi doğrultusunda hukuk da dâhil olmak üzere bütünsel bir metodolojik arayışı somutlaştırmaya yönelirken, hukukçular, hukukun kapalı yapısı içinde belirli hukuksal sonuçlara ulaşmayı yeterli görmüşlerdir². Savigny'den günümüze hukuk dünyasının geleneksel eğilimi hukuksal araştırmaların yöntemini elden geldiğince hukuksal ölçülerle biçimlendirmek, araştırmalarda hukuk dişı öğeleri dar kapsamda değerlendirmek ve araştırmaların yöneldiği özneleri farklı hukuksal yapıların hukukçu olan unsurlarıyla sınırlı bir çerçevede tutmak üzerine kurulmuştur ${ }^{3}$. Hukukun toplumsallıkla ilişki içinde bulunan yönü hukukun formel ve kurumsal görünümünün ardında perdelenmiş ve

Elizabeth Mertz, 'Introduction' in Elizabeth Mertz (ed), The Role of Social Science in Law (Ashgate 2008) XIII.

Richard A. Posner, 'Legal Scholarship Today’ (2001-2002) 115 Harv L R 1314, 1314. Posner 1960’l1 y1llara kadar hukuksal analizin temellerinin mantık, analoji, içtihatlar, emsal kararları takip etmeye ilişkin prensipler ile ortak akla dayandığını, fakat insani ve sosyal bilimlerden nadiren bahsedildiğini belirtir. 1920 ve 1930'lu yıllardaki Realistlerin etkinliğine karşın hukukun sosyal bilimlerden özenle ayrı tutulmaya çalışıldığından ve özerkliğe sahip bir disiplin olarak değerlendirildiğinden söz eder. Posner'e göre bu durum, II. Dünya Savaşı'nın ardından 1950'li yıllarda Amerikan siyasal sisteminin içindeki aktörlerin ideolojik yönden birbirlerine yakınlaşmalarından ve radikal sağın izolasyon ve ırkçılık gibi konular, radikal solun ise soğuk savaş nedeniyle itibar kaybetmesinden kaynaklanmaktadır. Bu dönemde Amerika'nın entelektüel hayatı sekülerizm, hümanizm, yurtseverlik ile siyasal 1lımlılık -merkeziyetçilik- üzerine kurulmuştu ve açık bir biçimde ideolojik çekişmelerden uzak bir görünüm arz ediyordu. Hukuk fakülteleri ve akademik çevresi de bu atmosferin dışında olmayıp hukuku politik olandan tamamen ayrı otonom bir görüngede tutuyor, sosyal bilimler ile ilişkilendirmeden ve onun aracılığıyla düşünmeden kendi doktrinel yapısı içinde değerlendiriyordu. Ibid 1316; Richard Posner, 'The Decline of Law as an Autonomous Discipline: 1962 - 1987' (1986-1987) 100 Harv L Rev 761, 765-766. Fakat hukuka yönelik söz konusu algı ve konumlama 1960'lı yılların yoğun politik ve ekonomik gündemi içinde hızla değişmiştir. Hukuk, bir taraftan sosyal bilimlerle daha fazla ilişki içinde olan disiplinler arası bir alan olarak analiz edilmeye başlanmış, diğer taraftan hukukun politik, ekonomik ve toplumsal konularla bağlantılı etkileşimsel süreçlerine daha sıklıkla atıf yapılır olmuştur. 
hukuksal araştırmanın konusu içinde kendisine ancak son sıralarda yer bulabilmiştir. Böylece hukukun toplumsal fonksiyonuna ilişkin incelemeler hukukçulardan ziyade başta sosyologlar olmak üzere sosyal bilimlerin farklı disiplinlerinin araştırmacılarına bizatihi hukukçuların irade ve inisiyatifleriyle devredilmiştir. Ancak hukukun sosyal bilimlerin bulgularından imtina etmesinin öncelikli sonucu, bir bütün olarak hukukun düzen fonksiyonu itibariyle yerine getirdiği toplumsal yönü ağır basan olgusal düzeydeki işlevselliğinin gelişen ve değişen sosyo-ekonomi politik gerçeklikleri takip etme ve gerekliliklerini karşılamadaki yetersizliği şeklinde ortaya çıkmıştır. Hukuk, bir bilim olma yeterliliğine ve kapasitesine iyelik iddiası içinde kendini, toplumsal dönüşümün dinamiklerinden ve bu dönüşümü araştırmaya yönelen metodolojilerden soyutladığı ölçekte içe kapanık dogmatik bir anlatıya dönüşmüştür.

Hukukun, kendini salt hukuksal kurum ve normatif düzenlemelerle sınırlandırarak belirlilik ve kesinliğe ulaşma yönündeki tercihi, bu anlamıyla sosyal bilimlerin verilerinden yararlanmaya dönük isteksizliği, yapısal karakter ve işleyişinin uzun dönemde kendine has bir düzen olarak olgunlaşması neticesini doğurmuştur. Hukukun söz konusu kendine özgü biçimlenmesinin sebepleri; hukuk düzeninin, reel ekonomi politikle süregiden simbiyoz yaşamından, hegemonik iktidar ilişkilerinin uzantısı ve onların süreğenliğinin meşruiyet kaynağı olarak hem devletin ideolojik bir aygıtı hem de baskı aygıtının muharrik gücü olmasından ${ }^{4}$ ve doğrudan öznelere yönelmiş potansiyel zorlayıcı - baskıcı niteliğinden kaynaklanmaktadır. Ancak bu noktada bilhassa hukuksal aktörler açısından, son derece girift ve zor bir sürecin varlığından da bahsetmek gerekir. 19. yüzyılda olduğu gibi 20. yüzyılda, hatta günümüzde de özellikle karar verici konumunda bulunan hukukçular açısından bu zor ve girift sürecin, hukukçuların kendilerini çoğunlukla formalist bir uzanımda tutup dünyaya hukuksal çerçeveyle sınırlı bir perspektiften bakmaya devam etmelerinin temel mazereti olmaya devam ettiği söylenebilir.

Gerçekten hukukçuların sosyal bilimler ile aralarına koydukları mesafe bir taraftan hukuk eğitiminin formalist ve dogmatik kalıpçılığından kaynaklanırken diğer taraftan hukukun doğrudan bireylerin hayatları üzerindeki etkinliği, belirleyiciliği ve zorlama gücüyle ilgilidir. Hukukçular sosyal bilimcilere nazaran sadece toplumun ve onu oluşturan bireylerin sistem içindeki konum, alışkanlık ve davranışlarını inceleyerek anlamlandıran ve sınıflandıran kişiler olmayıp, toplumsal yaşam içinde ortaya çıkıp hukukun konusuna giren eylemlerin hâlihazırdaki normatif kurallar sistematiği içindeki karşılığını bulmaya çalışan, gerektiğinde zora dayalı yaptırım süreçlerinin işlemesinde nihai kararı veren bir yapının, hukuk sistematiğinin ve onun uygulamasının yönlendiricileridirler. Dolayısıyla karar verme süreçlerinde bulundukları nihai konum onları çoğunlukla halihazırdaki toplumsal gerçeklikten

Konuyla ilgili daha ayrıntılı bir analiz için bkz. Louis Althusser, İdeoloji ve Devletin İdeolojik Aygıtları (Alp Tümertekin tr, İthaki 2003) 69-71. 
uzaklaştırarak kurallara atıfla daha statüko yanlısı tercihlere; ama kısmen de olsa önceden öngörülebilir ve tahmin edilebilir sonuçların bulunup serimlenmesine yöneltmektedir. Sosyal bilimcilerin bu yönden hukukçularda olmayan imkânlara sahip olduklarından bahsedilebilir; onlar geri çekilip daha kesin sonuçlara ulaşmak için araştırmalarını yeniden biçimlendirebilirler ${ }^{5}$. Buna karşın hukukçular, ister avukat, ister hâkim ya da akademisyen olsun benzer eğitim süreçlerinden geçmiştirler; evet ya da hayır, suçlu ya da suçsuz gibi kesin hükümleri vermek konusunda sorumluluk almanın baskısı ve sorumluluğu altındadırlar ${ }^{6}$. Bilhassa hüküm verme yetkesine sahip hukukçuların, sosyal bilimler disiplininde çalışan bir araştırmacının aksine, beklemek, her şeyi yeniden değerlendirmek, yanlış yaptıysa seçimini değiştirmek gibi imkânları yoktur ${ }^{7}$. Bu yoksunluk, karar verici konumunda bulunan hukukçuyu her hangi bir hataya düşmemek ve verdiği hükmün meşruiyetinin sağlanabilmesi gibi nedenlerden ötürü var olan toplumsal gerçekliklerden uzaklaştırmakta; salt normatif kurallara dayanmaya ya da farklı kaygılarla da olsa içtihatlar arası uyumsuzluğa sebebiyet vermemek dürtüsüyle önceden verilmiş bir kararı takip etmeye yöneltmektedir. $\mathrm{Bu}$ durum çoğunlukla hukukçunun niçin normatif alanın dışına çık(a)madığının veya çıkmaması gerektiğinin mazeretini oluşturduğu gibi hukukun muhafazakâr statükocu uygulaması ve metodolojisini de mütemadiyen beslemektedir. Hukuki karar vermenin ağır sorumluluğu altında tercih, vicdanen yerindeliği tartışmalı görünse ve karar veren organ bunun farkında olsa dahi gerektiğinde toplumsal gerçekliklerin göz ardı edilmesi ve normatif düzenin sürdürülmesi şeklinde bir yargısal hükümle sonuçlanmaktadır. Önceden belirlenmiş kurallar ile düzene riayette somutlaşan bu yaklaşım, son kertede hukuksal istikrara bir göndermeyle kendi meşruiyetini kazanıyormuş gibi görünüyorsa da yarattığı sonuçlar itibariyle bir taraftan hukuk aracılığıyla ekonomi politik sistemin yeniden üretilmesine katkı sunarken diğer taraftan hukuksal olanı toplumsal gerçekliklerden uzaklaştırmaktadır. Hukuksal hüküm verme süreçleri ile sosyal bilimler araştırması neticesinde ortaya çıkan bulguların uygulamaya yansıtılmasındaki tereddütler, hukukun kendi tekdüze kural ve düzen yapısı içinde bâtınileşmesi ve katılaşmasıyla sonuçlanırken; hukukçular adaleti, normatif kurallara mümkün mertebede riayetin bir uzantısı biçiminde kabul etmeye yönelmekte ve şekli bir fenomen haline getirmektedirler.

\section{Hukukun Dışa Açılımı: Disiplinler Arası Metodolojilerin İmkânı}

19. yüzyıldan 20. yüzyılın başlarına kadar liberal hukuk düzenlerinde uygulamadan doktrine hukuk dünyasındaki hâkim eğilim, içinde çeşitli farklılıklar ve ayrılıklar taşımakla beraber yukarıda belirtilen çerçevede sosyal bilimler ile mesafeli, hukukun belirli düzeyde soyutlanmasına dayanan hukuki pozitivist bir görünüm arz etmiştir.

Mertz (n 2) XIV.

Ibid.

Ibid. 
Birbirlerinden esaslı biçimde ayrı noktalardan hareket ederek farklı sonuçlara ulaşan, fakat özünde hukuk ile sosyoloji arasındaki ilk bağlantıları kuran ve modern kapitalist toplum içinde hukukun işlevini sorgulamaya yönelen; bu bağlamda hukuk sosyolojisine ilişkin günümüze kadar uzanan birçok görüş ve harekete ilham kaynağı olan Durkheim, Weber, Marx gibi önemli teorisyenlerin yaklaşımlarının özellikle hukuk uygulaması içindeki etkileri uzun süre cılız kalmıştır. Bununla birlikte hukuk ile sosyoloji arasındaki bağın kurulması ve onun sosyolojik araştırmanın konusu haline gelmesiyle birlikte hukukun toplumsal düzen fonksiyonunun, toplumsal kontrol süreçlerinde oynadığı rol ve araçsal niteliği itibariyle kavranabilmesi imkânı sağlanmıştır ${ }^{8}$. Bu süreç içinde önce doktrinel düzeyde başlayan hukukun toplumsal boyutuyla da değerlendirilmesi gerektiğine ilişkin tartışmalar, zamanla hukuk uygulaması üzerinde de etki göstermeye başlamış ve 19. yüzyılın katı formalist kalıplara dayanan geleneksel hukukçuluğunun kabulleri sorgulanır hale gelmiştir.

Bir proje olarak aydınlanma düşüncesinin "ilerlemecilik" ilkesi, toplumun hızla ve sürekli değişen ihtiyaçlarının karşılanabilmesi ve toplumsal ilişkilerin kontrol altına alınabilmesi için geleneksel politik sistemlerin doğrudan kural koyuculuk anlayışının ötesinde hukuk kurallarının da zamanın gereklilikleri doğrultusunda sosyolojik boyutlarıyla değerlendirilmesini zorunlu kılmıştır ${ }^{9}$. Söz konusu zorunlulukların fark edilmesi, hukukun sosyal bilimler ile çok boyutlu ilişkiler kurmasıyla ve farklı disiplinlerin bilgilerinin karşılıklılık sürecinde değerlendirilmek suretiyle analizine dayanan yeni hukuksal metodolojilerin geliştirilmesine odaklanılmasıyla sonuçlanmıştır. Uygulama safhasını da kapsamak üzere hukuksal sorunların sadece hukuksal materyallerle sınırlı bir çerçevede çözülmeye çalışılmasının yetersizliği anlaşılmış ve sosyal bilimlere referansla ve onun kılavuzluğundan yararlanılarak bu sorunların üstesinden gelinmesi fikri güç kazanmıştır ${ }^{10}$. Bilhassa Amerikan Realizminin şekillenmesinin ardından hukuk sosyolojine olan ilgi hem doktrinde hem kısa sürede mahkeme kararlarına da yansıyacak biçimde uygulama düzeyinde

Alan Hunt, 'The Problematisation of Law in Classical Social Theory' in Reza Banakar and Max Travers (eds), An Introduction to Law and Social Theory (Hart 2002) 16; Huntington Cairns, Law and the Social Sciences (Augustus M. Kelley 1969) 149-151.

9 Hunt (n 8) 16. Aydınlanmanın politik sistem ve onunla bağlantılı olarak hukuk düzeni üzerindeki asıl önemli etkisi, geleneksel egemenlik anlayışının -Weberyen bir terimle ifade etmek gerekirse- rasyonel ve yasal egemenliğe tahavvülü ile bunun neticesinde insanın doğuştan sahip olduğu kabul edilen bir takım temel hakların hukuk aracıllğıyla güvenceye alınması ve hukukun da paralel biçimde rasyonel ve bürokratik nitelikli düzenleyici bir araç haline gelmesidir. Hukuk düzeninin ve normlar sisteminin modern bürokratik yönetimin gerekliliklerini karşılayabilmek için rasyonelleștirilmesi, ayrıca hukukun toplumu denetleme ve toplumsal ilişkileri gerek bireyler gerek birey ile devlet arasındaki düzenlemeye dönük müdahaleciliği, onun geleneksel fonksiyonunun çok daha ötesinde politik ve ekonomik sistemle bütünleşmesi sonucunu doğurmuştur. Ancak söz konusu bütünleşme süreci hukuka atfedilen ve onunla özdeşleştirilen objektivite, tarafsızlık, öngörülebilirlik gibi vasıflar aracılı̆̆ıyla ve aynı zamanda hukukun meşruiyetin yegâne kıstası haline getirilmesi sayesinde daha az görünür kılınabilmiş̦tir. Bakınız Max Weber, Economy and Society - An Outline of Interpretive Sociology (Guenther Roth and Claus Wittich eds, University of California 1978) 868 and 876; Hunt (n 8) 23; Dragan Milovanovic, An Introduction to the Sociology of Law (3th edn, Criminal Justice 2003) 65; Dragan Milovanovic, Weberian and Marxian Analysis of Law: Development and Functions of Law in a Capitalist Mode of Production (Ashgate 1989) 142.

10 Cairns (n 8) 3-4. Hukukun sosyal bilimlere referansla yeniden düşünülmesi gerektiğine ilişkin en önemli çıkışlardan biri François Geny tarafından yapılmıștır. Geny'e göre hukuk sadece normatif düzenlemeler olmayıp hukuk düzeninin temeli ahlaki, ekonomik, fiziki, psikolojik ve politik bir dizi değişkene bağıdır. Bunlar hukuk bilimi tarafından sosyal bilimlerin verileri aracılığıla ampirik olarak analiz edilip hukuksal teknik ve kurguların uygulanması suretiyle hukuka eklemlenirler. $\mathrm{Bu}$ nokta geleneksel hukukçuluğun ve hukuksal pozitivizmin metodolojisiyle tam bir karşıtlık içindedir. Altan Heper, Serbest Hukuk Akımı-Sosyal Bir Olgu Olarak Hukuk- (On İki Levha 2016) 37. 
artmış; hukuk ile sosyal bilimler arasında kurulan rabıtadan hareketle teori ve pratikte sosyo-hukuksal çalışmalara hız verilmiştir. Hukukun sosyolojik nitelikleri itibariyle değerlendirilmesi gerekliliğinin kavranması ve toplumsal fonksiyonuyla kamusal nitelikli düzen işlevinin daha açı biçimde ortaya konulabilmesi gayesi, hukuksal konularda ampirik araştırmalar yapılması gerektiği yönündeki tartı̧maları da başlatmıştır. Böylece süreç içinde hukuk, tedricen, salt normatif anlamda takip edilmesi gereken formel yöntemlerden müteşekkil bir disiplinden toplumsal boyutu da düşünülmesi gereken disiplinler arası bir paradigma ve araştırma sahası haline gelmiştir.

Petrazycki ve Ehrlich gibi hukukçuların çalışmaları bu bağlamda bir dönüm noktasına işaret etmektedir. Durkheim, Weber ve Marx'ın aksine, hukuk ile politik ve ekonomik yapı arasında modernleşme ve rasyonelleştirme süreçlerinde ortaya çıan durumlarla ilgilenmeyen bu hukukçular, hukukun toplumsal niteliği ve sosyal bilimlerle olan ilişkileri gibi hususlara yoğunlaşmışlardır ${ }^{11}$. Başka bir ifadeyle hukukun gerek normatif düzeyde gerek toplumsal hareketlilik içinde nasıl işlediğinin ortaya konabilmesi ve anlaşılabilmesi özelinde, hukukçuların formalist zihniyetten hareketle izlediği geleneksel pozitivist metodolojiyi, sosyal bilimlerin bulguları ile ampirik araştırmaların sonuçlarının çok boyutlu olarak değerlendirmeye alındığı disiplinler arası bir yöne çevirmek istemişlerdir. Hukuk kavramını ampirik bir tabandan hareketle tartışmaya başlayıp sosyal bilimleri hukuksal analizin parçası haline getirmeye uğraşmışlar; hukuksal pozitivizmin hukuku, salt otoritenin emirlerinin uzantısı biçimindeki kabulü yerine daha geniş bir perspektifte toplumsal bir olgu şeklinde nitelendirmeye yönelmişlerdir ${ }^{12}$. Hukukun toplumsal boyutunu büyük oranda görmezden gelen dogmatik kavramcı hukuk anlayışına ve hukuksal pozitivizme yönelik güçlü bir tepkiyi ifade eden hukuka ilişkin bu sosyolojik yönelim içinde Ehrlich ve Petrazycki' nin yanı sıra Jhering, Geny, Lundstedt gibi isimler de yer almıştır $^{13}$. Bununla birlikte Petrazycki ve Ehrlich'in çalışmalarının hukukun ampirik teorisinin kurulması aşamasında özel bir önem arz ettikleri belirtilmelidir. Hukukun ampirik teorisinin kurulabilmesi, hukuk sosyolojisi açısından bilhassa hukukun normatif teorisinin aşılarak sosyal bilimlerden de yararlanılan yeni bir metodolojik anlayışın geliştirilebilmesi yönünden son derece önemli bir aşama olarak karşımıza çıkmaktadır.

\section{Leon Petrazycki: Psikolojizm ve Ampirizm}

Petrazycki, Comte'un sosyoloji ve sosyal bilimler için izlediği yöntemi benzer biçimde hukuka tatbik etmek istemiş; "hukuk politikası bilimi” olarak isimlendirdiği

\footnotetext{
Bakınız Reza Banakar, 'Sociological Jurisprudence' in Reza Banakar and Max Travers (eds), An Introduction to Law and Social Theory (Hart 2002) 35-37.

12 Ibid 33-34.

13 Klaus A Ziegert, 'The Sociology Behind Eugen Ehrlich's Sociology of Law' (1979) 7(3) International Journal of Sociology of Law 225, 226-227.
} 
ve demokratik bir toplumun inşası için özünde mevcut hukuk düzeninin ilerlemesi ve gelişimini sağlamaya dönük özel bir disiplin şeklinde tanımladığı metodolojik yaklaşımı aracılığıyla ampirik - psikolojik nedenselliğe dayanan kendi hukuk teorisinin inşasına çalışmışıı ${ }^{14}$. Petrazycki, hukuksal yaklaşımının temeline bilimsellik olgusunu koyarak kendi hukuk kavrayışını tüm geleneksel hukuk anlayışlarından ayırmaktadır; ona göre kendi yaklaşımı dışında zamanının hukuk teorilerinin hiç biri bilimsel nitelik taşımamakta ve hukuksal gerçekliği başarılı biçimde açıklayamamaktadır ${ }^{15}$.

Petrazycki'nin hukuk politikası bilimi olarak adlandırdığı, tümdengelim ve ampirik doğrulama biçiminde iki boyutu bulunan metodolojik tercihi, özünde psikoloji ile hukuk arasında belirli bir ilişki kurulmasına dayanmakta; böylece temel psikolojik öncüller üzerinden tümdengelimci sonuçlar çıkarılmasını ve bu sonuçların mümkün oldukça tümevarımla doğrulanmasını amaçlamaktadır ${ }^{16}$. Başka bir ifadeyle tümdengelimci çıkarımların, başta istatistiki bulgular olmak üzere olgusal girdilerden yararlanmak suretiyle ampirik bir tümevarımsal analizle doğrulanmasına dayanmaktadı1 ${ }^{17}$. Petrazycki'nin hukuk politikası olarak adlandırdığı yaklaşımının bir diğer önemli boyutu da, ayrıntılı bir incelemesi her ne kadar bu çalışmanın sınırlarını aşıyorsa da, hukukun sosyal mühendislik işleviyle kullanılmasında ortaya çıkmaktadır. Petrazycki, hukuk politikası yaklaşımıyla kendisinden sonra daha sık dillendirilecek olan hukukun sosyal mühendislik işleviyle kullanılmasını açık bir biçimde öneren kişi olmuştur ${ }^{18}$. Hukuk, psikoloji ve ampirizm arasında kurduğu bağlantılarla hukukun çok boyutlu ve disiplinler arası perspektiften incelenmesine yönelen ilk hukukçulardan olup ampirik çalışmaların temellerinden biri olarak kabul edilen gözlem olgusu üzerine yoğunlaşmıştır. Onun açısından hukuksal olguların incelenmesi de, fiziksel veya tinsel dünyanın olgularını araştırmaya yönelen çalışmalara benzer biçimde, esasen gözleme dayanan bir metodoloji üzerinden yürütülmelidir ${ }^{19}$. Fakat hukukun olgusal niteliği, onun dışsal ya da maddi dünyaya ait bir vakıa olmasından ziyade insanın gözlem, karşılaştırma ve analiz yoluyla kavrayabileceği, varlık olarak insanın tinsel dünyasına ait psişik bir olgu olmasından kaynaklanmaktadır ${ }^{20}$. Bu bağlamda Petrazycki hukukun varoluşunu doğrudan onun

14 Nicholas S. Timasheff, 'Introduction' in Leon Petrazycki, Law and Morality (Hugh W. Babb tr, Harvard 1955) XXII; Hugh W Babb, 'Petrazhitskii: Science of Legal Policy and Theory of Law' (1937) 17 BUL Rev 793, 797; M A Reisner, 'The Theory of Petrazhitskii: Marxism and Social Ideology' in John N Hazard (ed), Soviet Legal Philosophy (Hugh W Babb tr, Harvard 1951) 75; Adam Podgorecki, 'Unrecognized Father of Sociology of Law: Leon Petrazycki - Reflections based on Jan Gorecki's Sociology and Jurisprudence of Leon Petrazycki' (1980-1981) 15 Law \& Soc’y Rev 183, 186.

15 Timasheff, Introduction (n 14) XXVIII.

16 Babb, Petrazhitskii: Science (n 14) 817.

17 Ibid 817-818.

18 Jan Gorecki, 'Social Engineering through Law' in Jan Gorecki (ed), Sociology and Jurisprudence of Leon Petrazycki (University of Illinois 1975) 116; Krzysztof Motyka, 'Law and Sociology: The Petrazyckian Perspective' in Michael Freeman (ed), Law and Sociology - Current Legal Issues - Vol 8 (Oxford 2006) 138.

19 Petrazycki (n 1) 12.

20 Hugh W Babb, 'Petrazhitskii: Theory of Law' (1938) 18 BUL Rev 511, 513-514; S A Golunskii and M S Strogovich, 'The Theory of The State and Law' in John N Hazard (ed), Soviet Legal Philosophy (Hugh W. Babb tr, Harvard 1951) 415. 
toplumsal nitelikli bir özellik göstermesiyle ilişkilendirmeyip daha ziyade insanın varoluşuna dayanan psikolojik bir mahiyet çerçevesinde anlamlandırmaktadır. Başka bir ifadeyle ona göre hukuksal olgular normların değil, insan zihninin birer uzantısı ve deneyiminin özel türüdürler ${ }^{21}$.

Bu doğrultuda Petrazycki hukuksal süreçlerin ampirik doğası üzerine düşünerek, hukuku, gerçekliğin bir parçası kabul etmiş, fakat onun gerçekliğinin psikolojik bir nitelik gösterdiğini ve zihinsel süreçlerin iç gözlemine dayanan bir yöntemle ${ }^{22}$ deneyimlenerek -deneysel olarak serimlenerek- anlaşılabileceğini savunmuştur ${ }^{23}$. Kendi kendine gözlem anlamına gelen iç gözlem yöntemi, ilk olarak deneyimlenen süre boyunca irdelenen tinsel olguya yönelik içsel ilginin yönlendirilmesi ve ardından daha önce deneyimlenmiş eylemin imgesinin ya da düşüncesinin içe dönük gözlemi olmak üzere iki düzeyi kapsamaktadır ${ }^{24}$. Dolayısıyla Petrazycki açısından iç gözlemin hem hâlihazırda kişinin sürekli olarak varlığını ve eylemselliğini zihinsel bir olgu -tinsel bir fenomen- olarak gözlemleyip deneyimlemesi hem de deneyimlediği eylemleri daha sonra imgesel ve zihinsel boyutta tekrar değerlendirmek suretiyle içsel olarak gözlemlemesi şeklinde gerçekleşen iki boyutundan söz edilebilir. $\mathrm{Bu}$ yaklaşım Petrazycki'nin pozitif hukuk - sezgisel hukuk ayrımının ampirik düzeyde anlamlandırılabilmesi açısından önem arz etmektedir.

Petrazycki, gerçek hukukun ampirik yönden algilanabilmesinin psikolojik araştırmaların sonuçlarıyla ilintili olduğunu söylemiş; buradan hareketle hukuku hem dışsal hem içsel yönden gözlemlenebilen ve deneysel olarak üzerinde çalışabilen özel bir olgu olarak kabul etmiştir ${ }^{25}$. Keza iç gözleme ilişkin her tür yöntemin hukuksal

${ }^{21}$ Jan Gorecki, 'Preface' in Jan Gorecki (ed), Sociology and Jurisprudence of Leon Petrazycki (University of Illinois 1975) IX; Jan Gorecki, 'Leon Petrazycki' Jan Gorecki (ed), Sociology and Jurisprudence of Leon Petrazycki (University of Illinois 1975) 3. Doktrinde Petrazycki'nin antinormativist çizgiyi benimsediğine yönelik ortak bir kabul vardır. Bununla birlikte Gorecki, Petrazycki'nin normları hukuk teorisinin kavranabilir öznesi saymayarak, normun yerine deneyimi koymaya dönük yaklaşımının kendi içinde bazı çelişkiler barındırdığı düşüncesindedir. Gorecki'ye göre Petrazycki, hukuksal gerçekliği ve olguları psikolojik ve ampirik bakımdan ele alarak anlamlandırmaya çalıştığı süreçlerde normu bir kenara bırakıyor ve dışlıyorsa da, hukuku sosyal mühendislik işlevi itibariyle değerlendirdiği zamanlarda normları deneyime nazaran daha fazla ön plana çıkarmaktadır. Ibid 13. Petrazycki'nin hukukun sosyal mühendislik işleviyle normlar arasında kurduğu ilişkiye ilişkin ayrıntılı bir analiz için bakınız Gorecki, Social (n 18) passim.

22 Petrazycki'nin hukuk teorisindeki psikolojik yaklaşımının önemli bir boyutunu iç gözlem oluşturmaktaysa da, hukukun neye tekabül ettiğinin açıklanabilmesi için dışsal olguların gözlemlenmesine ve değerlendirilmesine de son derece önem verdiği belirtilmelidir. Aleksander W. Rudzinski, 'Petrazycki’s Significance for Contemporary Legal and Moral Theory' (1976) 21 Am J Juris 107, 121.

23 Timasheff, Introduction (n 14) XXIII-XXIV; Petrazycki (n 1) 13-14. Ayrıca bakınız Norman K Denzin, 'Interaction, Law, and Morality: The Contributions of Leon Petrazycki' in Jan Gorecki (ed), Sociology and Jurisprudence of Leon Petrazycki (University of Illinois 1975) 68-69; N S Timasheff, An Introduction to the Sociology of Law (Harvard University Committee 1939) 53; Reisner (n 14) 75- 6.

24 Petrazycki (n 1) 13. Petrazycki'e göre örneğin kişinin diş ağrısı çekerken kendi diş ağrısını gözlemlemesi dar anlamda kendi kendini gözlemin birinci düzeyiyken, diş ağrısı geçtikten sonra daha önce yaşadığı diş ağrısını hatırlayarak onun imgesel ya da düşünsel düzeyde iç gözlemini yapması ikinci düzeyi ifade eder. Hatta iç gözlem yöntemi için kişiye yönelmiş herhangi bir dış eylem veya etkinin varlığına da gerek yoktur. Kişi hiçbir şey yapmadan iç gözleme dayalı deneysel araştırmaları psikolojik tecrübeleri vasıtasıyla da gerçekleştirebilir. Utanç, gurur, hırs, minnettarlık veya kıskançlık gibi doğuştan gelen tecrübeler, insanın hayal gücü dâhilinde özel durumların birleşimlerine karşılık gelen duyguları hatırlatma kapasitesine sahip canl1 resimlerdir. Ibid 13-14.

25 Babb, Petrazhitskii: Science (n 14) 807; Rudzinski (n 22) 109. 
olguların incelenmesinde de bütünüyle uygulanabilir olduğunu savunmuştur ${ }^{26}$. $\mathrm{Bu}$ noktada Petrazycki'nin buyurucu - atfedici deneyimlerin normatif olgulara karş1lık gelip gelmedikleri temelinde bir pozitif hukuk - sezgisel hukuk ayrımına yöneldiğinden bahsedilebilir ${ }^{27}$. Ona göre sezgisel hukuk kavramının oluşumu, her biri bilimsel yöntemlerin yardımı ile ifade edilebilecek, gözlemlenip incelebilecek olgularla ilgilidir ${ }^{28}$. Dolayısıyla sezgisel hukuk pozitif hukuktan ilk olarak entelektüel içeriğe sahip olması ve normatif olgu düşüncesinin yokluğu yönüyle farklılaşır ${ }^{29}$. Pozitif hukuk, özellikle resmi hukuk ${ }^{30}$ biçiminde, yığın olarak büyük ya da küçük belirli bir grup insana yönelik birörnek kural kalıbını sunarken; esnekliği ve sürekliliği sayesinde sezgisel hukukun içeriği, her bireyin karakteri, terbiyesi, eğitimi, toplumsal pozisyonu, mesleği, kişisel tanışıklıkları ve ilişkileri gibi bireyler için değişebilir niteliği haizdir ${ }^{31}$. Sezgisel hukukun sadece bireysel düzlemde ortaya çıktığı da düşünülmemelidir; belirli bir ailenin, camianın, grubun ya da toplumsal sınıfin yani farklı toplumsal katmanların da sezgisel hukukundan bahsedilebilir ${ }^{32}$. Bu nitelikteki daha geniş sezgisel hukuklar dahi pozitif hukukun aksine tek biçimli ve kalıplaşmış hukuk niteliği göstermezler, zira Petrazycki'nin yaklaşımı açısından ne kadar birey varsa o kadar sezgisel hukuk vardır ${ }^{33}$. Buradan hareketle sezgisel hukuku, geleneksel hukukçuluğun yukarıdan aşağıya deklare edilen normatif ve tekçi hukuk anlayışından aşağıdan yukarıya yönelmiş hukuksal çoğulluklar olarak nitelendirmek yanlış olmayacaktır.

Petrazycki açısından pozitif hukukun normatif düzeyde geçmişte oluşturulmuş olması ve içeriğinin zamansal olarak geçmişin gerçekliğinde sabitlenmesi, güncel ekonomik ve tinsel yaşamın gerisinde kalarak toplumsal gelişim üzerinde geciktirici etki doğurmasınaneden olurken, sezgisel hukuk serbest değişkenlik veuyarlanabilirliğe sahiptir ${ }^{34}$. Bu durum, her ne kadar normatif olgu düşüncesi olmasa da ve pozitif hukukla

\footnotetext{
26 Petrazycki (n 1) 14.

27 Ibid 224. Petrazycki hukukun buyurucu - atfedici niteliğinden genel olarak bir tarafın belirli haklara sahip olmasını, diğer tarafın da bu haklar karşısındaki yükümlülüklerini ifade etmektedir. Burada çift taraflı bir ilișki söz konusu olup hak sahibi tarafa belirli bir hakkın atfedilmesi, diğer tarafa ise hakka uygun biçimde davranmasının buyurulması söz konusudur. Ibid 153; Yasemin Işıktaç and Umut Koloş, Hukuk Sosyolojisi (İstanbul Bilgi Üniversitesi 2015) 81; Umut Koloş, 'Leon Petrazycki ve Hukukun Gerçekliği Sorunu: Bir Psikolojik Hukuk Kuramı' in Saim Üye et al (eds), Prof. Dr. Adnan Güriz'e Armă̆an (Ankara Üniversitesi 2016) 511-512.

28 Petrazycki (n 1) 224

29 Ibid 225.

30 Petrazycki'nin hukuka ilişkin pozitif hukuk - sezgisel hukuk ayrımının yanı sıra resmi hukuk - resmi olmayan hukuk şeklinde yaptığı bir ayrım daha vardır. Ibid 221.

31 Ibid 225; Gorecki, Leon (n 21) 8; Koloș (n 27) 517.

32 Petrazycki (n 1) 225.

33 Ibid 225-226.

34 Ibid 226. Petrazycki’ye göre pozitif yasalar -ne kadar güncel olursa olsun- sürekli ve kesintisiz bir şekilde gelişen yaşamın gerisinde kalmaktan kaçınamaz. Ibid.
} 
kıyaslandığında daha basit ve yetersiz bir fikri içeriği sahipse de ${ }^{35}$, sezgisel hukukun önermelerinin yapısal anlamda daha kapsamlı ve geniş uygulanabilirliğine imkân tanımaktadır ${ }^{36}$. Gerçekten pozitif hukukta davranış kurallarının bağlayıcı gücü ve işlevi, bağımlı ve otoriter - normatif olgulara dayandırılmış olarak düşünüldüğünden zaman, mekân ve kişiler açısından sınıllılıklarla malûldür; Petrazycki'ye göre bu sınırlılıklar ve onların pozitif hukuksal bilinçlilik alanındaki belirleyici önemleri, sınırsız uygulanabilirliği olan sezgisel hukuk bilincine tamamen yabancıdır ${ }^{37}$. Bu yönüyle pozitif hukuk düzenlemelerindeki yükümlülük ve haklar geçici, yerel ve benzeri yapısal nitelikler gösterirken, sezgisel hukuk evrensel, her zaman ve her yerde var olan bir yapıya sahiptir ${ }^{38}$. Hukuki güdülenmeyle tanımlandığı ölçüde kişinin kendisinin veya başkasının davranışlarının iç gözlem metodu ile incelenmesi durumunda sezgisel hukukun bireysel davranış ve toplumsal olguların belirlenimi üzerinde ne kadar büyük ve önemli bir rol oynadığı ortaya çıkacaktır ${ }^{39}$. Pozitif hukuk düzenlemelerinin tümüyle nüfuz etmediği komşuluk, arkadaşlık, akrabalık, tanıdıklık, yoldaşlık ilişkilerinde ya da bireylerin aşk hayatında sezgisel hukukun etkinliğinin başat konumda olduğu görülür ${ }^{40}$. Dolayısıyla bireysel ve toplumsal alanın gündelik etkinliğinin sürekli yeniden üretildiği pek çok ilişki biçiminde sezgisel hukukun pozitif hukuksal alanın belirleyiciliğini aşan bir yürürlüğünden söz edilebilirr ${ }^{41}$. Keza borçlar hukuku ya da ticaret hukukunun sınırları içinde değerlendirilebilecek, meta mübadelesinin gerçekleştiği pek çok günlük rutin iktisadi ilişkinin hukukun normatif yapısının dışında, sezgisel hukukun özgünlüğü içinde bireysel ve toplumsal gerçekliği inşa ettiği dikkat çeker.

Yukarıdan aşağıya dayatılan pozitif hukukun normatif emrediciliğgi, aşağıdan yukarıya doğru biçimlenen, bireysel ve toplumsal davranış kalıpları ile kamusal alanı kuşatan sezgisel hukukun karşısında geri çekilmekte; sezgisel hukukun etkinliği,

\footnotetext{
5 Petrazycki sezgisel hukukun her zaman içerik olarak mutlaka pozitif hukuktan daha iyi ya da mükemmel olmadığını da belirtir. Hatta çoğunlukla sezgisel hukukun içeriğinin pozitif yasadan daha düşük kalitede ya da geri nitelikte olması da mümkündür. Bireylerin sezgisel hukuku her ne kadar benzersiz ya da özgün nitelikte olsa da, bu sezgisel hukukun niteliği bireysel gelişiminin koşullarına bağlı olduğundan farklılıklar gösterir, dolayısıyla ortaya çıkan sezgisel hukukun yetersiz hatta oldukça kötü olması sonucuyla da karşılaşılabilir. Aynı durum toplumsal grup ya da sınıfların sezgisel hukuku için de söz konusudur. Keza pozitif yasaların içeriği bu bağlamda toplumdaki grup veya sınıfların birçok sezgisel hukukundan daha iyidir. Belirli bir zamandaki belirli bir devletin yasası uyarınca vatandaşların sahip oldukları haklar, belirli toplumsal grup ya da sınıflardaki sezgisel hukukta var olan bireysel haklarla kıyaslandığında daha eşitlikçi bir biçimde inşa edilmiş olabilirler. Örneğin pozitif hukuk ilerici bir aile hukuku düzeni kurabilir, buna karşın toplumun belli katmanlarının sezgisel hukuku kadının kocasından şikâyetçi olmasını yasaklarken kocanın karısını dövmesine veya eziyet etmesine izin verebilir. Ibid 227.

36 Ibid 227-228

37 Ibid 228.

38 Ibid.

39 Ibid 229.

40 Ibid. Rudzinski'ye göre Petrazycki sezgisel hukuku sadece ahlak ve ideal toplumla ilgili felsefi kurguların bir konusu olarak değil, hukukun kendisindeki bir tür hukuksal olgu olarak nitelemiştir. Hukuk kavramını geleneksel hukukçuluğa göre çok daha geniş bir perspektifte tanımlayarak hukukun kiliselerde, spor müsabakalarında, çocukların odasında ya da mafyanın içinde de var olduğunu belirtmiştir. Rudzinski (n 22) 130. Dolayısıyla sezgisel hukuk hayatın her alanında var olan bir düzen olarak kabul edilebilir.

41 Ayrıca bakınız Petrazycki (n 1) 229.
} 
bireylerin pozitif hukuk ile onun araç ve kurumlarına başvurma tercihleriyle kıyaslandığından niceliksel olarak daha büyük bir kütleyi teşkil etmektedir. Gerçekten de Petrazycki açısından pozitif hukukun temel karakteristiği normatif niteliği nedeniyle başta biçimsel olmak üzere muhtelif sınırlılıklarla malul olduğu halde, sezgisel hukukun gerek bireyin zihinsel yaşamında gerek farklı toplumsal yapıların işleyişleri içinde süreklilik göstererek insanların eylem ve düşüncelerini yönlendirme gücüne sahip bir etkileyen olarak normatif düzenlemelerin de ötesinde bir anlam kazandığından bahsedilebilir. $\mathrm{Bu}$ anlam dünyasının özelliklerinin ve sezgisel hukukun etkinliğinin ortaya konabilmesi ise hukuksal pozitivizmin normu temel inceleme konusu yapan geleneksel yöntemleriyle gerçekleşemeyeceği için esasen sosyal bilimlerde kullanılan başta ampirizm olmak üzere metodolojik analizlerin hukuk alanında yeniden değerlendirilmesini ve kullanılmasını zorunlu kılmaktadır.

Petrazycki bu amaç doğrultusunda yeni hukuk biliminin ancak psikolojik bir olgu olarak psikoloji biliminin bulgularından yola çıkarak ve hukukun ampirik yöntemlerle incelenmesi sayesinde kurulabileceğini belirtmiştir ${ }^{42}$. Hukuksal gerçekliğin psikolojik karakterine ve hukukun mevcut toplumsal kültürün -aynı zamanda toplumun kültürel gelişimin- bir parçası ve sonucu olduğuna dikkat çekmiştir ${ }^{43}$. Petrazycki, psikolojizm olarak nitelendirilen bu yaklaşımında, duygu psikolojisi (emotional psychology) adını verdiği metodolojiyi kullanmak suretiyle hukuku, psikolojik bir olgu kabul etmekte ve realist bir perspektiften hareketle hukuksal normativistlerin tam aksi yönde hukuksal gerçekliğin araştırılmasına yönelerek onu bir vakıa, gerçek dünyanın bir olgusu biçiminde kavramaktadır ${ }^{44}$. Başka bir ifadeyle kendi hukuk teorisini çağdaşlarının aksine devlet hukuku olarak adlandırabilecek normatif kurallar çerçevesinde dar bir alana hapsetmemekte; hukuksal gerçekliğin ancak belirli insan davranışlarının gözlemlenerek anlaşılabilmesi halinde bulunabileceğini belirtmektedir ${ }^{45}$.

Sonuçta Petrazycki açısından hukuk biliminin ve hukukçunun temel görevlerinden biri olarak insanın psikolojik olgu dünyasının içinde biçimlenen sezgisel hukukun ne olduğunun iç gözleme dayanan ampirik yöntemlerle incelenmesi zorunluluğu ortaya çıkar. Hukukun sosyal bilimlerle, özel olarak sosyal bilimlerin psikoloji alanıyla buluşması tam da bu noktada, geleneksel hukuk metodolojilerinin yerine ampirizmin ikame edilmesiyle vücut bulmaktadır. Böylece hukuk, normatif önsel kabullerin ve

\footnotetext{
42 Timasheff, Introduction (n 14) XXX; Petrazycki (n 1) 22.

43 Timasheff, Introduction (n 14) XXXVI. Petrazycki, hukukun insanlara özgü bir olgu olduğunu vurgularken onun ancak kültürün -aynı zamanda dilsel gelişimin de- belirli bir evresine ulaşıldığında ortaya çıktığını belirtmektedir. Petrazycki (n 1) 12 .

44 Motyka (n 18) 125-126. Petrazycki’nin hukuku gerçek bir olgu olarak kavramasının somut örneklerini çeşitli çalışmalarında öne sürdüğü görüşlerde açıkça bulmak mümkündür. Petrazycki, Roma hukukunun veya medeni hukukun sosyo-ekonomik perspektiften hareketle yorumlanması gerektiğini önermekte; medeni hukuk kurumlarını ekonomik etkileri ve toplumun kültürel durumunu göz önüne alarak ve bunları birbirleriyle ilişkilendirerek değerlendirmek gerektiğini ifade etmektedir. Ibid 135 .

${ }_{45}{ }^{45}$ Rudzinski (n 22) 110-111. Ayrıca bakınız Fehmiye Ceren Akçabay, 'Hukuka Uymak ya da Uymamak İşte Tüm Mesele Bu: Psikolojik Hukuk Yaklaşımı Çerçevesinde Hukuka Uyma ve Meşruluk İlişkisi’ in Saim Üye et al (eds), Prof. Dr. Adnan Güriz'e Armağan, (Ankara Üniversitesi 2016) 44-45.
} 
pozitivizmin formalist kalıpçılı̆̆ ve gözlemsel süreçlerin uzanımında sosyal bilimlerle ilişkilendirilerek toplumsal gerçeklikte somutlaştırılmaktadır. Petrazycki'nin hukuk teorisi sosyolojik bir yaklaşımdan ziyade ${ }^{46}$ psikolojik kabulleri ön plana çıkaran bir görünüm arz etmekteyse de, söz konusu teorinin bilhassa kendisinden sonra gelen ve hukuk ile toplum arasındaki ilişkileri ele alan hukukçular üzerinde gözlem ve ampirik araştırmaya dayanan metodolojik arayışı teşvik etmesi itibariyle etkili olduğu yadsınamaz.

\section{Eugen Ehrlich: Toplumsalın Ampirik Gözlemi ve Yaşayan Hukuk}

Petrazycki hukuksal analize ilişkin araştırmalarında bireylerin hukuksal olgularla ilgili deneyimleri meselesine odaklanırken, Ehrlich daha ziyade pozitif hukuk ile yaşayan hukuk (living law) arasında belirli bir ilişki kurarak toplumsal ve hukuksal normlar konusuna yoğunlaşmıştır ${ }^{47}$. Ehrlich de Petrazycki gibi, hukukun salt hukuksal araçlarla ele alınabileceğine ilişkin hukuki pozitivist argümanları benimsemek yerine hukuki incelemeyi disiplinler arası bir alan kabul ederek ampirik yöntemleri ${ }^{48}$ ön plana çıkarmış ${ }^{49}$; bilimsel bir anlayışı benimseyerek ${ }^{50}$ hukuk ile başta sosyoloji olmak üzere sosyal bilimler arasında yeni bir bağlantı kurmaya yönelmiştir. Ehrlich açısından geleneksel hukukçuluk, hukuku, merkezileşmiş bir devletin ve bu devletin mahkemelerinin ihtiyaçlarını temin için değişken pratik amaçları takip eden göreceli bir tekniğe indirgeyerek fiili olgusal durumu maskelemekte; yapay sistemleştirmeler ve kavramlaştırmalarla hukuki gerçekliği ancak yüzeysel düzeyde kavrayabilmektedir ${ }^{51}$. Hukuki gerçekliğin yüzeysel düzeyde kavranabilmesinin sebebi, hukukçuların toplumsal olguları salt hukuksal bir dünya görüşü çerçevesinde normatif birsınırlandırma ile değerlendirerek hüküm vermesinden kaynaklanmaktadır. Gerçekten Ehrlich'e göre toplumsal olguların gözlemleme suretiyle başta sosyoloji olmak üzere sosyal bilimlerden hareketle bilimsel anlamda analiz edilmesi,

$46 \quad$ Petrazycki'nin hukuk teorisinin hukuk sosyolojisi üzerinde her ne kadar çok yönlü etkileri olmuşsa da kendisinin hiçbir çalışmasında hukuk sosyolojisi terimini kullanmadığı dikkat çeker. Podgorecki (n 14) 197.

47 Banakar (n 11) 43. Ayrıca bakınız Marc Hertogh, 'From 'Men of Files' to 'Men of the Senses': A Brief Characterisation of Eugen Ehrlich's Sociology of Law', in Marc Hertogh (ed), Living Law - Reconsidering Eugen Ehrlich (Hart 2009) 9; Mehmet Yüksel, Zakir Avşar and Kasım Akbaş, Hukuk Sosyolojisi (Anadolu Üniversitesi 2013) 176.

48 Ehrlich'in doğrudan ampirik araştırmalara yöneldiğini de belirtmek gerekir. 1909 yılında üniversitede "yaşayan hukuk semineri”" adı altında bir araştırma enstitüsü kurduğu ve öğrencilerle birlikte hukuk uygulamasının nasıl gerçekleştiğine yönelik çeşitli çiftlik, atölye ve ticarethaneleri kapsayan anket usulüne dayanan saha araştırmaları yaptığı bilinmektedir. Bununla birlikte ilk çalışmalarının Tarihçi Hukuk Okulu'nun perspektifini benimseyen bir zeminde geçmiş dönemin hukuksal kalıplarını esas aldığı söylenebilir. Fakat Ehrlich, yaşadığı dönemde tekrarlanan insanlar arası ilişkilerdeki hukuki olayların da ampirik araştırmasının yapılabileceğinin farkına varmıştır. Heper, Serbest (n 10) 50-51; ayrıca bakınız Ibid 90. Böylece normatif düzenlemelerden çok daha geniş bir uygulama alanı olan yaşayan hukuku incelemeye başlamıştır.

49 Bu noktada Ehrlich ile birlikte Serbest Hukuk Hareketi içinde ön plana çıkan Hermann Kantorowicz'in de hukuksal alanda yürütülecek çalışmalarda, hukuk sosyolojisi alanında gerçekleştirilecek ampirik araştırmaların çok önemli ve faydalı olacağına ilişkin bir yaklaşımı benimsediğini eklemek gerekir. Altan Heper, 'Almanya'da Hukuk Sosyolojisi Dersleri ve Kitapları Konusunda Bir İnceleme’ (2015) 2 (3) Hukuk Kuramı 1, 4.

50 İrem Burcu Özkan, 'Hukuku Yaşamda Bulmak: Eugen Ehrlich’in Hukuk Sosyolojisi Anlayışında Yöntem' in Yasemin Işı1ktaç (ed), Dönüşen Toplum - Dönüşen Hukuk II: Yöntem (Sümer 2016) 180.

51 Georges Gurvitch, 'Hukuk Sosyolojisinin Kurucuları ve Bugünkü Cereyanlar' (Hamide Topçuoğlu tr) (1973) 8 (3) AÜHFD $629,630-631$. 
olgular arasında neden - sonuç ilişkisi kurularak incelenmesi bir zorunluluk olarak hukukçuların karşısına çıkmaktadır ${ }^{52}$. Bu noktada Ehrlich'in bilim insanı ile sanatçı arasında kurduğu ilişkinin ${ }^{53}$ bir benzerini hukukçu ya da hukuk sosyoloğu cephesinde de kurmaya çalıştığından söz edilebilir.

Bilim insanı için araştırma yönteminin başlangıç noktası, dış dünyanın insan zihnine sunduğu izlenimler olup idealleştirilmiş dış izlenimlerin alınmasıyla her tümdengelim bir tümevarım tarafından öncelenmekte; bu süreçte tümevarım ve izlenimlerin alınması hızlı fakat bilinçli bir amaç olmadan gerçekleşirken sadece tümdengelim veya idealleştirmenin ardı sıra gelen süreci bilim insanının zihnine girmektedir ${ }^{54}$. Buradaki zihinsel sürecin öncelikle gözleme dayanmasından hareketle hukuk sosyolojisinin esasen bir gözlemleme bilimi olduğunu ve metodolojisinin de hukuksal alandaki toplumsal ve hukuki olguların ampirik incelemesine dayanması gerektiğini söylemek yanlış olmayacaktır ${ }^{55}$. Mamafih hukukçuların toplumsal olguların hukuksal analizi ve gözlemlenmesinde kendilerini normatif düzenlemelerle sınırlandırmadan, hukuksal alanın dışındaki toplumsal hayatın kendiliğinden işleyen düzeni içindeki kuralları, yani yaşayan hukuku da göz önünde tutan bir kavrayışla değerlendirmeye yönelmeleri gerekmektedir.

Döneminin egemen hukuk anlayışlarının tersine, hukukun kaynağını sadece pozitif hukuk düzenlemelerinde aramayan ve hukuksal pozitivizmin hukuk tanımını, hukukun toplumsal düzenleyicilik işlevinin anlaşılabilmesini imkânsız kıldığı için eleştiren ${ }^{56}$ Ehrlich'e göre yaşayan hukuk, hukuksal düzenlemelerle belirlenmemiş olsa bile yaşamın kendisine hâkim olan hukuktur ${ }^{57}$. Hukukun pozitif hukuk düzeniyle ilişkisini sorgulayan Ehrlich, hukuk normunun toplumsal normların içinde bulunabileceğini belirtmekte; bu bağlamda yaşayan hukuku da doğrudan devlet hukukuyla bağlantılandırmayıp farklı toplumsal grup ve birlikteliklerin düzenlemeleri içinde aramaktadır ${ }^{58}$. Onun açısından hukuk, yasalara hapsedilemeyecek bir gerçeklik olup ne olduğunun ortaya konabilmesi için hukuk kitaplarında anlatılanların ötesine gidilmeli; hem pozitif hukuk düzenlemelerinin ve yargısal hükümlerin oluşturulmasında toplumun oynadığ rol hem de söz konusu yasa ve hükümlerin

\footnotetext{
52 Heper, Serbest (n 10) 80 .

53 Bakınız Eugen Ehrlich, Fundamental Principles of the Sociology of Law, (Walter L. Moll tr, Russell \& Russell 1962) 472.

54 Ibid.

55 Ibid $473-474$.

56 Ibid 486; Roger Cotterrell, The Sociology of Law - An Introduction (2nd edn, Butterworths 1992), s. 26.

57 Ehrlich, Fundamental (n 53) 493. Özcan'a göre “Ehrlich'in yaklaşımında devletin koyduğu hukukun meşruluk sorunu, bunu yaşayan hukuka uygun olması ölçütüyle çözüme kavuşturulur. Hukukun kültürel cephesine vurgu yapan bu yaklaşım mahkemelerin de devletten çok toplumun organları olduğu görüşüne de gönderme yapar”. Mehmet Tevfik Özcan, Hukuk Sosyolojisine Giriş (4th edn, On İki Levha 2011) 55.

58 Hertogh (n 47) 3; Cahit Can, Hukuk Sosyolojisinin Antropolojik Temelleri ve Genel Gelişim Çizgisi (2nd edn, Seçkin 2003) 156-157.
} 
toplumsal yaşam üzerinde nasıl etkinlik gösterdikleri açılanmalıdır ${ }^{59}$. Hatta ona göre pozitif hukukun soyut önermeleri, yaşayan hukukun belirli bir kısmını içerdikleri zamanlarda bile yaşayan hukuku da kapsayan geniş anlamda hukukun en durgun tabakasını teşkil ederler ve her zaman yaşayan hukukla kıyaslandığında daha geride kalan düzenleme biçimleri olarak ortaya çıkarlar ${ }^{60}$. Bu nedenle hukukun toplumsal yaşam içindeki pratikleri incelenmeli, dogmatik hukukun yapısal işleyişinden ziyade Ehrlich'in yaşayan hukuk olarak adlandırdığı hukuksal gerçeklik dünyası araştırılmaya başlanmalıdır.

Ehrlich yaşayan hukukun nasıl araştırılacağı ve tespit edileceği hususunda yargı kararları başta olmak üzere modern hukuki dokümanların incelenmesi ile genel anlamda toplumsal yaşamın ve onun işleyişinin gözlemlenmesi şeklinde iki farklı kaynağın kullanabileceğini söyler ${ }^{61}$. Ehrlich'in modern hukuki dokümanların temeli olarak gördüğü yargı kararlarının önemi, pozitivist hukukçuların kabullerinin aksine, yargısal hüküm tesisinde normatif dayanağın nasıl belirlendiği ya da yorumlandığına ilişkin formalist gerekçelendirme zaviyesinde değil; esasen bu hükümlerin verilmiş olduğu toplumsal yaşam içinde gerçekleşen olguların bir tasvirini yansıtmalarındadır ${ }^{62}$. Bununla birlikte yargısal kararlar toplumsal yaşam içinde ortaya çıkan tüm ilişki biçimlerini ve gerçekliği, çok azı dava konusu haline geldiği için, asla yeterli düzeyde yansıtamazlar; dolayısıyla yargısal kararların toplumsal olgulara ilişkin içeriklerinden elde edilen sonuçların her zaman sosyolojik yöntemlerin kullanılması suretiyle toplumsal yaşamın gözlemlenmesi aracılığıyla desteklenmesi gerekmektedir ${ }^{63}$. Dava konusu edilen toplumsal yaşam içindeki olgular genelde menfaat çatışmalarının sadece küçük bir bölümünü yansıttığı gibi karşılıklı mübadele, uzlaşı ve çatışmasız hukuki ilişkilere ilişkin de herhangi bir veri sağlayamayacağından, yaşayan hukukun özellik ve işleyişinin ortaya konulabilmesi için geniş anlamda toplumsal yapı ve ilişkilerin ekonomik, politik ve kültürel içeriklerinin gözlemlenmesine yönelmek gerekecektir.

Yaşayan hukuku anlayabilmek için öncelikle pozitif hukuk düzeninin dışındaki gündelik hayatın, gelenek ve teamüllerin, ticaretin ve yasalar tarafından olumlu veya olumsuz anlamda düzenlenmiş olsun ya da olmasın her türlü birliğin -toplumsal

\footnotetext{
David Nelken, 'Ehrlich's Legacies: Back to the Future in the Sociology of Law?' in Marc Hertogh (ed), Living Law Reconsidering Eugen Ehrlich (Hart 2009) 244. Ayrıca bakını Ülker Gürkan, Hukuk Sosyolojisine Giriş (3rd edn, Siyasal 1999) 60.

60 Gurvitch (n 51) 633.

61 Ehrlich, Fundamental (n 53) 493-494.

62 Ibid 494.

63 Ibid 495.
} 
grubun- işleyiş pratikleri çok boyutlu olarak gözlemlenmelidir ${ }^{64}$. Burada yukarıda da değinildiği üzere ticaret ve iş yaşamı içinde, taraflar arasında gerçekleştirilen pek çok iktisadi nitelikli ilişkinin irade özgürlüğü ve sözleşme serbestisi gibi temel liberal ön kabullerden hareketle normatif çerçevenin dışına çıkmadan, fakat geniş bir özerklik alanı içinde yaşayan hukukun parçasını oluşturduğu söylenebilir. Yargısal süreçlerin konusu haline gelmeden işleyen iktisadi - hukuksal yaşamda kullanılan sözleşmeler, belgeler veya diğer her tür materyal bu anlamda hukukçunun inceleyip anlamlandırabileceğ $i^{65}$ temel malzemeyi oluşturduğu gibi diğer toplumsal olguların gözlemlenmesi de günlük yaşamın iktisadi olmayan işleyişinin temel paradigmalarının ortaya çıkartılabilmesine imkân tanıyacaktır.

Gözlemleme sürecinin merkezine hukuk sosyolojisini koyan ${ }^{66}$, böylece maddi gerçekliği bütünsel biçimde serimlemek isteyen $E_{\text {hrlich }}{ }^{67}$, sosyolojiyi de kendi hukuksal yaklaşımının olmazsa olmazı yaparak normatif ve uygulamalı bir perspektif yerine ampirik ve açıklayıcı bir yöntemsel tercihte bulunmuş; sosyolojik temelden hareket eden bir hukuk metodolojisinin hukukçuların topluma karşs sorumluluklarını gerçek anlamda yerine getirebilmeleri bağlamındaki önemini vurgulamıştır ${ }^{68}$. İnsanlar arası ilişkileri ya da günlük yaşamı hukuksal normlardan bağımsız görerek ${ }^{69}$ toplum içinde süre giden hukuksal ilişkilerin herhangi bir pozitif hukuk sistemine atıf yapmadan dahi tanımlanabilmesini olanaklı kabul etmiştir ${ }^{70}$. Hukuk her ne kadar sadece norma dayalı bir yapı olarak gösterilmeye çalışılıyorsa da normlar hukukun sonradan türetilmiş formları olup hukukun ilk varoluşu toplumsal ilişkiler içinde biçimlenmiştir ${ }^{71}$. Bu nedenle hukuk toplumsal süreçlerin uzanımında sadece normatif düzeyle sınırlandırılmamalı, toplumsal ilişkilerin bir parçası olarak düşünülmeli ve

\footnotetext{
Ibid 493. Ayrıca bakınız Ziegert, The Sociology (n 13) 250-254. Ehrlich'in yaşayan hukuk yaklaşımının pozitif hukuk düzenini tamamen görmezden gelerek yok saydığı düşünülmemelidir. Aksine Ehrlich bir toplum içinde bir arada işleyen hukukların hepsinin -yürürlükteki hukuk normları (devlet hukuku), uygulamadaki hukuk (hukukçuların hukuku), toplumsal normlar- değerlendirilmesi gerektiğini belirtir. Örneğin yürürlükteki hukuk normları, gelenek ya da âdet kuralları gibi toplumsal nitelikli normları baskı altına alarak etkisiz kılmış ya da uygulamadaki hukuk pozitif hukuk kurallarından farklılaşmıș veya toplumsal normların işlerliği ve gücü yürürlükteki normların etkinliğini zayıflatmıș olabilir. Dolayısıyla toplumsal girdilerden beslenen yaşayan hukuk, birbirinden farklı hukukların etkileşim süreçlerinin bir çıktısı şeklinde tanımlanmalıdır. Stefan Vogl, 'Eugen Ehrlich's Linking of Sociology and Jurisprudence and the Reception of his Work in Japan' in Marc Hertogh (ed), Living Law - Reconsidering Eugen Ehrlich (Hart 2009) 102. Yürürlükteki hukuk ve uygulamadaki hukuk kavramları ile ilgili olarak bakınız Salif Nimaga, 'Pounding on Ehrlich. Again?' in Marc Hertogh (ed), Living Law - Reconsidering Eugen Ehrlich (Hart 2009), s. 161 - 162.

65 Ehrlich, Fundamental (n 53) 495. Bu bağlamda Ehrlich evlilik sözleşmeleri, alım satım sözleşmeleri, hasılat kiraș1, inşaat kredisi sözleşmeleri, ipotekli borçlar, vasiyetnameler, miras sözleşmeleri, dernek ya da iş ortaklıklarına ilişkin hükümlerden hareketle yaşayan hukukun işleyişine ilişkin çıkarımların yapılabileceği kanısındadır. Ibid.

${ }^{66}$ Ehrlich açısından hukuk sosyolojisinin pratik fonksiyonu toplumsal yaşamın farklı alanlarında işleyen yaşayan hukukun keşfedilebilmesi ve sistematik analizinin gerçekleştirilebilmesi özelinde ortaya çıkmaktadır. Cotterrell, The Sociology (n 56) 32 .

67 Ehrlich, Fundamental (n 53) 501; Klaus A. Ziegert, 'World Society, Nation State and Living Law in the Twenty-first Century' in Marc Hertogh (ed), Living Law - Reconsidering Eugen Ehrlich (Hart 2009) 230. Ehrlich'e göre hukuk düzeninin normatif içeriğe sahip olması hukuk sosyolojisi bağlamında yürütülecek çalışmalar açısından herhangi bir sorun arz etmemektedir. Vogl (n 64) 98.

${ }_{68}$ K. Alex Ziegert, 'A Note on Eugen Ehrlich and the Production of Legal Knowledge' (1998) 20 Sydney L Rev 108, 112 Ayrica bkz. Vogl (n 64) 119-121; Ziegert, World (n 67) 230

69 Ehrlich, Fundamental (n 53) 358-359; Ibid 477.

70 Timasheff, An Introduction (n 23) 26.

${ }^{71}$ Eugen Ehrlich, 'The Sociology of Law' (Nathan Isaacs tr) (1922-1923) 36 Harv L Rev 129, 143-144.
} 
normlar da toplumsal düzenle uyum içinde olmalıdır ${ }^{72}$. Örneğin mülkiyet, taşınmaz hakları, sözleşmeler, miras gibi olgular salt hukuksal nitelikli kavramlar değildir; özünde belirli bir ekonomik gelişmişlik düzeyinin ürünleridir ve toplumsal yaşam ile ilişki içinde varlıklarını sürdürmektedirler ${ }^{73}$. Gerçekten söz konusu olgular hâkim üretim biçiminin, piyasa koşullarının ve ekonomik altyapının zorunlulukları ve ihtiyaçları doğrultusunda hukuki düzenlemelerin bir parçası haline gelmekte, belirli sınıfsal konumları, çıkarları ve toplumsal ilişki süreçlerini yansıtmaktalardır. $\mathrm{Bu}$ bakımdan hukuksal anlamlarının çok ötesinde bir ekonomi politik gerçekliğe tekabül etmekte, toplumsal yaşam üzerinde hukukun normatif kalıpçılığıyla tanımlanamayacak derecede etki göstermektedirler.

Ehrlich, hukuk düzeninin ne olduğunun anlaşılabilmesi için hukuk kitaplarına bakılmasından ziyade toplumsal yaşamın de facto biçimde toplumsal grup ve ağlar tarafından nasıl organize edildiğinin gözlemlenmesi ve araştırılması gerektiği düşüncesindedir ${ }^{74}$. Hukuksal normlarla bunların müeyyide ve zorlayıc1lıklarının etkinliğini, toplumsal yapı içinde varlıklarını sürdüren farklı grup ve kurumları karşılaştırmak suretiyle ortaya koymaya çalışmaktadır ${ }^{75}$. Bu bağlamda farklı etnik ve kültürel grupların gelenek ve alışkanlıklarına dair ampirik araştırmalarda bulunarak pozitif hukuk normlarının etkinliği ile toplumsal düzeydeki işleyişlerinin yanı sıra günlük yaşam içinde hukuksal süreçlerin fiilen nasıl gerçekleştiği meselesine odaklanmaktadır ${ }^{76}$. Birbirinden farklı ve ayrışmış toplumsal kesimlerin yaşantıları içindeki fonksiyonuna yoğunlaşarak hukuku tamamen toplumsal bir olgu olarak değerlendirmekte; onun pozitivist anlamdaki geçerliliğini sorgulamaktadır. Araştırmasını, devletin normatif hukuksal düzeniyle aynı anda mevcut bulunan, tarihsel ve kültürel birikimin sonucu olarak toplumsal ilişki süreçlerinde ortaya çıkan, varlığını bu ilişkisel düzeyden alarak sürdüren gayrı resmi karakterli "diğerlerinin hukuklarına" yöneltmekte; hukukun pozitivist ve formalist çeperlerini kırarak çok boyutlu analizinin gerçekleştirilmesini hedeflemektedir. Dolayısıyla Ehrlich'in hukuksal yaklaşımının, geleneksel hukukçuluğun hukukun analizine ilişkin normatif dogmatikliğini aşarak onun ötesinde hukuksal olguların ampirik incelemesini ön plana çıartan ve hukuksal metodolojiyi sosyal bilimlerin bulgularıyla değerlendirip yeniden anlamlandırmaya yönelmiş bir içeriğe sahip olduğu söylenebilir.

\section{Değerlendirme}

Petrazychi ve Ehrlich'in hukuk teorilerinin hukuk sosyolojisi üzerindeki etkilerini tam olarak betimlemek güç olsa da her iki hukukçunun bilhassa çok hukukluluk ve

\footnotetext{
2 Ibid 144.

73 Ehrlich, Fundamental (n 53) 477-478.

74 Banakar (n. 11) 43.

75 Stewart Macaulay, 'The New Versus The Old Legal Realism: “Things Ain’t What They Used To Be"' (2005) Wis L Rev $365,386$.

76 Banakar (n 11) 43.
} 
onun uzanımında hukuksal çok merkezlilik (legal polycentricity) gibi yönelimler üzerinde etkili olduğu, bunun yanı sıra Pound'un uygulamadaki hukuk (law in action) yaklaşımının Ehrlich'in yaşayan hukuk kavramıyla paralellikler arz ettiği söylenebilir ${ }^{77}$. Petrazycki gibi Ehrlich'in de kendilerinden sonraki sosyo-hukuksal çalışmalara asıl katkılarının ise metodolojik yönden olduğu belirtilmelidir. Bu katkı pek çok hukukçu ve sosyal bilimcinin, Petrazycki ve Ehrlich'in hukuka ilişkin geliştirdikleri sosyo-hukuksal metodolojiden hareketle yeni yaklaşımlar ortaya çıkarabilmelerini sağlamıştır. Örneğin Petrazycki'nin önemli takipçileri arasında, ayn zamanda öğrencileri de olan Gurvitch, Sorokin ve Timasheff gibi isimler ön plana çıkarken Malinowski'nin de hukuk ile antropoloji arasındaki ilişkileri açıklamaya dönük çalışmalarında Petrazycki'nin hukuk anlayışını takip ettiği dikkat çeker ${ }^{78}$. Yine Pound'un belirttiği gibi Petrazycki'nin, ilk Amerikan Hukuki Realistleri üzerinde doğrudan bir tesiri olmamışsa da daha sonraki Realist hukukçu kuşağı hem hukuk sosyolojisi hem de hukuksal ampirizm araştırmaları dolayımıyla daha yoğun biçimde etkilediği göz ardı edilmemelidir ${ }^{79}$. Buna karşın Ehrlich'in hukuk sosyolojisi alanındaki çalışmalar üzerinde daha yoğun ve Petrazycki ile kıyaslandığında daha erken dönemlerde görülen bir nüfuzundan bahsetmek mümkündür ${ }^{80}$. Farklı biçimlerde olmakla birlikte görüşleri, öncelikle Almanya' da Serbest Hukuk Okulu'nu (Freirechtsschule), 1920'lerde Japon hukukçularını, 1930'lardan itibaren başta Pound ve Llewellyn olmak üzere Amerikan Realistleri ile İskandinav Realistlerini, 1940'larda hukuk ve antropoloji, daha sonra ise hukuk eğitimi ve daha geniş kapsamda olmak üzere hukuk sosyolojisi üzerine çalışan pek çok kişiyi etkisi altına almıştır ${ }^{81}$.

Sonuç olarak her iki hukukçu da hukuku, tek başına normatif bir yapı olarak değerlendirmemiş; hukuksal pozitivizm ve normatif hukuk teorilerinin kabullerinden çok daha geniş bir perspektifte sosyal bilimlerin farklı disiplinleriyle ilişkilendirerek yeni bir konuma yerleştirmişlerdir. Onların hukuku sosyal bilimlerle ilişkilendirmesi, gözlem ve ampirik araştırmaları hukuksal incelemelerin bir parçası haline getirebilmelerine imkân vermiş ve 20. yüzyllın ilerleyen dönemlerinde

Ibid 46; Motyka (n 18) 128-131. Bununla birlikte Pound'un uygulamadaki hukuk kavramı ile Ehrlich'in yaşayan hukuk kavramı birbirlerinden bir takım önemli farklılıklar içermektedir. Uygulamadaki hukuk kitaplarda yazan hukuk ile hukuk uygulamacılarının güncel pratikleri arasındaki farklılık ve boşluklara odaklanmaktadır. Yaşayan hukuk ise yurttaşların yaşamları içinde toplumun üyesi olarak tabi bulundukları zorunluluklara atıf yapmaktadır. Uygulamadaki hukuk yaklaşımı okullarda öğretilen hukukla uygulamada vuku bulan hukuk arasındaki boşluklara yönelmekte, yaşayan hukuk ise yukarıda da değinildiği üzere normlara, bu normların müeyyide ve zorlayıcılıklarına, toplumsal yapı içindeki çeșitli kurumların ve grupların araştırılmasına odaklanmaktadır. Bu yönüyle yaşayan hukuk kavramı daha radikal bir pozisyonu işgal etmekte ve hukuk uygulaması içinde hukukun nasıl işlediğinden ziyade toplumsal yaşam içinde pozitif hukuk düzeninin dışında ortaya çıkan hukukla bağlantılı süreçleri ele almaktadır. Macaulay (n 75) 385-386; Ziegert, A Note (n 68), 112 and 121-122; Roger Cotterrell, 'Ehrlich at the Edge of Empire: Centres and Peripheries in Legal Studies' in March Hertogh (ed), Living Law Reconsidering Eugen Ehrlich (Hart 2009) 83-84; Nimaga (n 64) 157-158. Ayrıca bakınız David Nelken, 'Law in Action or Living Law? Back to the Beginning in Sociology of Law' (1984) 4 Legal Stud 157, passim.

78 Motyka (n 18), 120-121.

79 Roscoe Pound, Jurisprudence - Vol I (West 1959) 344.

80 Ziegert, The Sociology (n 13) 227.

${ }_{81}$ Ziegert, A Note (n 68) 109; Ziegert, The Sociology (n 13) 227; Vogl (n 64) 95-96; Mathias W Reimann, 'Free Law School' in David S Clark (ed), Encyclopedia of Law \& Society: American and Global Perspectives - Vol 2 (Sage 2007) 605-606. 
hukuk ve sosyal bilimler ilişkisi üzerine çalışan pek çok hukukçu ve araştırmacının çalışmalarına da yön vermiş̧ir. Petrazycki ve Ehrlich'in öncülüğünü yaptı̆̆ı, hukuku, bireysel ve toplumsal olgulardan hareketle ampirik metotların kullanılması suretiyle analiz yöntemi aynı zamanda hukuk ile sosyal bilimler arasında disiplinler arası metodolojik araştırmaların başlamasının da ilk aşamasını oluşturmuştur. $\mathrm{Bu}$ disiplinler arası yaklaşım bilhassa hukukun ne olduğu ya da ne olması gerektiği gibi soruların salt hukuksal dünya görüşünün yarattı̆̆ı normatif dar çerçevenin dışında yeni bir anlam kazanarak yeniden sorgulanabilmesine imkân tanımıştır.

Hakem Değerlendirmesi: Dış bağımsız.

Çıkar Çatışması: Yazar çıkar çatışması bildirmemiş̧tir.

Finansal Destek: Yazar bu çalışma için finansal destek almadığını beyan etmiștir.

Peer-review: Externally peer-reviewed.

Conflict of Interest: The author has no conflict of interest to declare.

Grant Support: The author declared that this study has received no financial support. 


\section{Bibliyografya/Bibliography}

Akçabay FC, 'Hukuka Uymak ya da Uymamak İşte Tüm Mesele Bu: Psikolojik Hukuk Yaklaşımı Çerçevesinde Hukuka Uyma ve Meşruluk İlişkisi' in Üye S et al (eds), Prof. Dr. Adnan Güriz'e Armağan, (Ankara Üniversitesi 2016) 39-71.

Althusser L, İdeoloji ve Devletin İdeolojik Aygıtları (Alp Tümertekin tr, İthaki 2003).

Babb HW, 'Petrazhitskii: Science of Legal Policy and Theory of Law' (1937) 17 BUL Rev 793-829.

-- 'Petrazhitskii: Theory of Law' (1938) 18 BUL Rev 511-578.

Banakar R, 'Sociological Jurisprudence' in Banakar R and Travers M (eds), An Introduction to Law and Social Theory (Hart 2002) 33-49.

Cairns H, Law and the Social Sciences (Augustus M. Kelley 1969)

Can C, Hukuk Sosyolojisinin Antropolojik Temelleri ve Genel Gelişim Çizgisi (2nd edn, Seçkin 2003).

Cotterrell R, The Sociology of Law - An Introduction (2nd edn, Butterworths 1992).

-- 'Ehrlich at the Edge of Empire: Centres and Peripheries in Legal Studies' in Hertogh M (ed), Living Law - Reconsidering Eugen Ehrlich (Hart 2009) 75-94.

Denzin NK, 'Interaction, Law, and Morality: The Contributions of Leon Petrazycki' in Gorecki J (ed), Sociology and Jurisprudence of Leon Petrazycki (University of Illinois 1975) 63-82.

Ehrlich E, 'The Sociology of Law' (Isaacs N tr) (1922-1923) 36 Harv L Rev 129-145.

-- Fundamental Principles of the Sociology of Law, (Moll WL tr, Russell \& Russell 1962).

Golunskii SA and Strogovich MS, 'The Theory of The State and Law' in Hazard JN (ed), Soviet Legal Philosophy (Babb HW tr, Harvard 1951) 351-425.

Gorecki J, 'Leon Petrazycki' in Gorecki J (ed), Sociology and Jurisprudence of Leon Petrazycki (University of Illinois 1975) 1-15.

-- 'Preface' in Gorecki J (ed), Sociology and Jurisprudence of Leon Petrazycki (University of Illinois 1975) IX-XI.

-- 'Social Engineering through Law' in Gorecki J (ed), Sociology and Jurisprudence of Leon Petrazycki (University of Illinois 1975) 115-132.

Gurvitch G, 'Hukuk Sosyolojisinin Kurucuları ve Bugünkü Cereyanlar' (Hamide Topçuoğlu tr) (1973) 8 (3) AÜHFD 629-642.

Gürkan Ü, Hukuk Sosyolojisine Giriş (3rd edn, Siyasal 1999).

Heper A, 'Almanya' da Hukuk Sosyolojisi Dersleri ve Kitapları Konusunda Bir İnceleme' (2015) 2 (3) Hukuk Kuramı 1-16.

-- Serbest Hukuk Akımı -Sosyal Bir Olgu Olarak Hukuk- (On İki Levha 2016).

Hertogh M, 'From 'Men of Files' to 'Men of the Senses': A Brief Characterisation of Eugen Ehrlich's Sociology of Law', in Hertogh M. (ed), Living Law - Reconsidering Eugen Ehrlich (Hart 2009) 1-17.

Hunt A, 'The Problematisation of Law in Classical Social Theory' in Banakar R and Travers M (eds), An Introduction to Law and Social Theory (Hart 2002) 13-31.

Işıktaç Y and Koloş U, Hukuk Sosyolojisi (İstanbul Bilgi Üniversitesi 2015).

Koloş U, 'Leon Petrazycki ve Hukukun Gerçekliği Sorunu: Bir Psikolojik Hukuk Kuramı' in Üye S et al (eds), Prof. Dr. Adnan Güriz'e Armağan (Ankara Üniversitesi 2016) 493-540.

Macaulay S, 'The New Versus The Old Legal Realism: "Things Ain't What They Used To Be"” (2005) Wis L Rev 365-403. 
Mertz E, 'Introduction' in Mertz E (ed), The Role of Social Science in Law (Ashgate 2008) XIII XXX.

Milovanovic D, Weberian and Marxian Analysis of Law: Development and Functions of Law in a Capitalist Mode of Production (Ashgate 1989).

-- An Introduction to the Sociology of Law (3th edn, Criminal Justice 2003)

Motyka K, 'Law and Sociology: The Petrazyckian Perspective' in Michael Freeman (ed), Law and Sociology - Current Legal Issues - Vol 8 (Oxford 2006) 119-140.

Nelken D, 'Law in Action or Living Law? Back to the Beginning in Sociology of Law' (1984) 4 Legal Stud 157-174.

-- 'Ehrlich's Legacies: Back to the Future in the Sociology of Law?' in Hertogh M (ed), Living Law - Reconsidering Eugen Ehrlich (Hart 2009) 237-272.

Nimaga, S, 'Pounding on Ehrlich. Again?' in Hertogh M (ed), Living Law - Reconsidering Eugen Ehrlich (Hart 2009) 157-175.

Özcan MT, Hukuk Sosyolojisine Giriş (4th edn, On İki Levha 2011).

Özkan İB, 'Hukuku Yaşamda Bulmak: Eugen Ehrlich'in Hukuk Sosyolojisi Anlayışında Yöntem' in Işıtaç Y (ed), Dönüşen Toplum - Dönüşen Hukuk II: Yöntem (Sümer 2016) 151-184.

Petrazycki L, Law and Morality (Babb HW tr, Harvard 1955).

Podgorecki A, 'Unrecognized Father of Sociology of Law: Leon Petrazycki - Reflections based on Jan Gorecki's Sociology and Jurisprudence of Leon Petrazycki' (1980-1981) 15 Law \& Soc'y Rev 183-202.

Posner R, 'The Decline of Law as an Autonomous Discipline: 1962 - 1987' (1986-1987) 100 Harv L Rev 761-780.

-- 'Legal Scholarship Today' (2001-2002) 115 Harv L R 1314-1326.

Pound, R, Jurisprudence - Vol I (West 1959).

Reimann MW, 'Free Law School' in Clark DS (ed), Encyclopedia of Law \& Society: American and Global Perspectives - Vol 2 (Sage 2007) 605-606.

Reisner MA, 'The Theory of Petrazhitskii: Marxism and Social Ideology' in Hazard JN (ed), Soviet Legal Philosophy (Babb HW tr, Harvard 1951) 71-82.

Rudzinski AW, ‘Petrazycki’s Significance for Contemporary Legal and Moral Theory' (1976) 21 Am J Juris 107-130.

Timasheff NS, An Introduction to the Sociology of Law (Harvard University Committee 1939).

-- 'Introduction' in Petrazycki L, Law and Morality (Babb HW tr, Harvard 1955) XVIII - XXXVIII.

Vogl S, 'Eugen Ehrlich's Linking of Sociology and Jurisprudence and the Reception of his Work in Japan' in Hertogh M (ed), Living Law - Reconsidering Eugen Ehrlich (Hart 2009) 95-123.

Yüksel M, Avşar Z and Akbaş K, Hukuk Sosyolojisi (Anadolu Üniversitesi 2013).

Weber M, Economy and Society - An Outline of Interpretive Sociology (Roth G and Wittich C eds, University of California 1978)

Ziegert KA, 'The Sociology Behind Eugen Ehrlich's Sociology of Law' (1979) 7(3) International Journal of Sociology of Law 225-273.

-- 'A Note on Eugen Ehrlich and the Production of Legal Knowledge' (1998) 20 Sydney L Rev 108-126.

-- 'World Society, Nation State and Living Law in the Twenty-first Century' in Hertogh M (ed), Living Law - Reconsidering Eugen Ehrlich (Hart 2009) 223-236. 